University for Business and Technology in Kosovo

UBT Knowledge Center

UBT International Conference

2015 UBT International Conference

Nov 7th, 9:00 AM - 5:00 PM

\title{
New interpretation of sovereignty
}

Erveina Gosalci

University for Business and Technology, erveina.gosalci@ubt-uni.net

Ardian Emini

University for Business and Technology, ardian.emini@ubt-uni.net

Follow this and additional works at: https://knowledgecenter.ubt-uni.net/conference

Part of the Law Commons

\section{Recommended Citation}

Gosalci, Erveina and Emini, Ardian, "New interpretation of sovereignty" (2015). UBT International Conference. 6.

https://knowledgecenter.ubt-uni.net/conference/2015/all-events/6

This Event is brought to you for free and open access by the Publication and Journals at UBT Knowledge Center. It has been accepted for inclusion in UBT International Conference by an authorized administrator of UBT Knowledge Center. For more information, please contact knowledge.center@ubt-uni.net. 


\title{
New interpretation of sovereignty
}

\author{
Erveina Gosalci ${ }^{1}$, Ardian Emini ${ }^{2}$ \\ UBT - Higher Education Institution \\ \{erveina.gosalci ${ }^{1}$, ardian.emini $\left.{ }^{2}\right\} @$ ubt-uni.net
}

\begin{abstract}
After the World War Two, the World has been facing different human rights breaches which cannot be resolved only by a single state, no matter how powerful it is. These human rights breaches include: genocide, ethnic-cleansing and other mass-atrocities are to be considered 'problems without passport" 95 . Nations 'face threats that no nation can resolve by acting alone and opportunities that can be exploited if all nations work together' ${ }^{96}$.

In the same time these issues have raised other important issues and debates and tensions between the protection of human rights in one side and sovereignty on the other side. The question that has been raised is which of them should prevail?

It was the Canadian Government in 2001 which sponsored the International Commission on Intervention (ICISS). One of the main aims of this commission was the creation of a new normative framework in order to justify military interventions in case of mass-atrocities, in order to ensure that the situation of Rwanda or 'Kosovo'97 will not be repeated again. It was the initiator of the Responsibility to Protect (R2P) principle which was first formulated by the International Commission on Intervention (ICISS) in 2001. It was a significant step toward the changes of the UN's legal framework in line with the changes of reality.

In 2005 world leaders agreed that all states had the responsibility to protect their citizens, and if any state fails to do so, than it is a duty of the international community to protect people against violation of human rights, atrocities etc.

The reason why the authors have chosen this topic is because Responsibility to Protect invokes one of the most important norms of the contemporarily international law; it is the operating language in case of humanitarian crises; and also it is the main argument of political and legal debates.
\end{abstract}

Keywords: Responsibility to Protect, Sovereignty, Human Rights, Genocide; UN,

\section{Introduction}

Sovereignty as a concept has three special historic moments: The first moment, is considered to be around $16^{\text {th }}$ and $17^{\text {th }}$ century, with the treaty of Westphalia, when sovereignty concept was closely related to the divine power and the monarch. Then with the historical developments, especially during the French Revolution and Industrial Revolution, in the focus of sovereignty it was the nation state or people and in the end after the both World Wars, that exhausted the humankind with mass murdering and the evaporation of many generations, the main focus became the Human Rights. Especially after the developments of the Cold War and the triumph of the liberalism, the Human Rights became the main issue. Now days, when many weak and failed countries or failing countries are operating, we have become witnesses/spectators of massive crimes towards the people of these countries. Such cases, as former Yugoslavia, Rwanda, Sudan, East Timor etc., are real indicators demonstrating that today's world is unsafe, with more weak or failing states. There is a real need for the international community to respond toward these crises, and UN is the mechanism to do that.

\footnotetext{
${ }^{95}$ As Kofi Annan has called them

${ }^{96}$ Annan, K. (2004) A more secure world: Our Shared Responsibility, Report of the SecretaryGeneral's High Level Panel on Threats, Challenges and Change, UN

97 The Responsibility to Protect: 'Precious Commitment' or a Promise Unfulfilled?* Global Responsibility to Protect 1 (2009) 114-132
} 
United Nations has been created in a moment when the biggest concern of the humankind was to recover the world after the fascism and to make peace between two antagonist "worlds" that were in the process of creation. Non-intervention was necessary to highlight the fact that, "these worlds" were the ones that didn't want to intervene on each-other to ensure a kind of status quo or world stability, but this wasn't fair towards humans. The human of isolated worlds has been a victim of lack of freedom and in the other side, the world of freedom was watching without acting. The Article 2 of the Charter of the United Nations seemed as the perfect solution for the antagonist bipolar world, but after the developments of 90s when the fall of the communism and the triumph of liberalism where a big step, this Article is insufficient to address the current problems. Issues after 90'ties are different, human rights are the main matter/topic of concern and the biggest challenge for international community. The challenge of International System still remains how to find a solution where the mechanism of International Organizations such as United Nations become functional in the addressing of the problem of the human rights in the weak states or failed or failing states. The world after 90 s has faced the big dilemma of intervention or non-intervention (military or other) in the states with enormous crises. The biggest discussion has been, whether it is allowed the intervention in the inner issues of the states from the Charter of United Nations, always by refereeing to the article 2 of the United Nations Charter. The frequent answers still remain that in the International System there is a new norm coming into life, which gives a bigger help to the doctrine of intervention. New norm of intervention is totally in contradict with actual discourse that disagrees with intervention, which pretends for a historical reverse where the power or raison d'état are the mechanism that move countries interest to intervene, and not any moral principle. I'll try to bring to the attention of this paper a short story of the evolution of the sovereignty concept in order to understand the moment of its evolution and then I'll treat different cases of intervention and non-intervention to understand the new interpretation of sovereignty with the evolution of new norms that support intervention.

\section{A short story of sovereignty/ Historic evolution of sovereignty (Treaty of Westphalia- UN charter)}

The notion of sovereignty was first enunciated at the Peace of Augsburg (1555) and it was clarified by the treaty of Westphalia 1648 to the explicit provisions relating to the sovereignty in the UN Charter ${ }^{98}$. Christopher Clapham noted that 'Westphalia sovereignty provided the formula under which territories which did not "count" as states, according to the criteria adopted by the European state system, could be freely appropriated - subject only to their capacity to conquer the incumbent power holders - by those which did count. 99

The concept of Sovereignty was a topic being elaborated even before Westphalia Treaty by Jean Bodin in $16^{\text {th }}$ century and then by Thomas Hobbes with Leviathan in $17^{\text {th }}$ century. The main focus of their studies was the legitimacy of the domestic hierarchy. They both treated Sovereignty from the perspective of domestic hierarchy and they didn't go much further, considering the fact that both philosophers have lived in the period when it was ruling the divine and natural law. It was then Jean Jacques Rousseau the author of Social Contract which focused his work on the doctrine of popular sovereignty. According to him "Each of us puts his person and all his power in common under the supreme direction of the general will; and in a body we receive each member as an invisible part of the whole" 100 , so the real expression of sovereignty become the general will. As Marc Weller says: The sovereignty was transferred from monarch personality to the politic entity even thought it was

${ }^{98}$ Heir A, Humanitarian Intervention After Kosovo-Iraq, Darfur and the Record of Global Civil Society,(Palgrave Macmillan, 2008)

99 Miller R, Respectable Oppressors, Hypocritical Liberators', in Deen Chatterjee and Don Scheid (eds), Ethics and Foreign Intervention,(Cambridge: Cambridge University Press, 2003), pg. 21550

100 Jean Jacques Rousseau, Social Contract taken at Victor Gourevitch, Rousseau, The Social Contract and other later Political Writings (Cambridge: Cambridge University Press, 1997) pg.50 
still absolute. ${ }^{101}$ This is the early period $\left(16^{\text {th }}-17^{\text {th }}\right.$ century $)$ of concept of Sovereignty, when the main focus was the Divine and the Monarchy as the ultimate power and body of Sovereignty.

Later on $\left(18^{\text {th }}-19^{\text {th }}\right.$ century) with the historical developments and consequences of French and Industrial Revolutions, Sovereignty's concept changed focus from Divine and the Monarchy to People and Nation state. According to the Hegel's philosophy on Sovereignty, it was the nation which fulfilled his historic destiny through state. One of the main principles of this philosophy was the principle of non-intervention on the inner issues of the states which protected the principle of sovereignty. Both periods were characterized by the concept of Sovereignty as an absolute power, when the non-intervention was alpha and omega of it, and with few or non interest toward human rights. Unfortunately it was necessary for the world to understand the real meaning of human rights, only when the awful developments of two World Wars in $20^{\text {th }}$ century happened. Only then the Sovereignty concept took in consideration the human prior to the state, and when intervention seems more than appropriate. Holocaust and massive violence were now leading the world's conscience. Under this situation the UN Charter came to life, but also considering the antagonist world being developed by communism and liberalism. For decades of this antagonism (Cold War), world got back to non-intervention with the fear and interest to keep the balances and status quo. During this period we can find a good tendency to bring together the concept of people's sovereignty and human rights all found in The Universal Declaration of Humans Rights, where it is expressed that, "The will of the people shall be the basis of the authority of government; this shall be expressed in periodic and genuine elections which shall be by universal and equal suffrage and held by secret vote or by equivalent free voting"102 The concept of people's sovereignty was broadening in the Conference on Security and Cooperation in Europe (CSCE). It was clearly stated through genuine and periodic elections the will of people will be freely and fairly expressed and talking about sovereignty the protection international human rights is an obligation of the participating states ${ }^{103}$ In this Conference the human rights where the main issue. The promotion of and protection should be the main priority and basic purposes of the governments. ${ }^{104}$

As it is seen so far it was the period after the Second World War when the human rights become a priority, and especially after the end of the Cold War, the concept of sovereignty started to change; it was the United Nations Secretary General Kofi Annan in 1999 which was appealing for the change of concept of sovereignty. "State sovereignty, in its most basic sense, is being redefined-not least by the forces of globalisation and international co-operation. States are now widely understood to be instrument at the service of their peoples, and not vice versa. At the same time individual sovereignty by which I mean the fundamental freedom of each individual, enshrined in the charter of the UN and subsequent international treaties-has been enhanced by a renewed and spreading consciousness of individual rights. $" 105$ This is considered as a new approach toward sovereignty, and it took more space after Kosovo crises. Starting from that time the sovereignty had another interpretation, and it was strongly connected with people's right of one state and people had the right to condition its application by government. Kofi's point of view on sovereignty was a good starting point for International Community to react on Kosovo's crisis.

101 Weller M , Contested statehood: The international Administration of Kosovo's Struggle for Independence, (Prishtine: Koha, M arch 2009), pg.42

${ }^{102}$ Declaration of Humans Rights art21(3)

103 Document of the Copenhagen Meeting of the Conference on the Human Dimension of the Conference for Security and Cooperation in Europe 29 June 1990 Art 5.21 (6) pg.5

104 Document of the Copenhagen Meeting of the Conference on the Human Dimension of the Conference for Security and Cooperation in Europe 29 June 1990

105 Annan K, 'Two Concepts of Sovereignty', (1999) The Economist,49-50 


\section{Challenges of article 2 (UN charter)-Sovereignty $v$ Humanitarian Intervention (definition of humanitarian Intervention, Who should, who can engage in humanitarian intervention)}

\section{The United Nations Charter}

The world after the World War II was a real mess, it was still the fear of the countries of a possible invasion by other countries, there were still shadows of war crimes, and the world was in a need of a new regulatory body such as United Nations. In its charter in 1945 the countries agreed to prevent each-other of using force or organizing military operations towards each-other. This was necessary for the antagonist world in creation, having in mind mutual fear of potential interventions.

"Taken as a whole the Charter essentially limits the right of states to use force internationally to cases of, first, individual or collective self-defence, and second, assistance in UN-authorized or controlled military operations." ${ }^{\prime 06}$ Most of the prohibitions are cited in the Article 2, the Article 2 paragraph 4 states that 'All Members shall refrain in their international relations from the threat or use of force against the territorial integrity or political independence of any state, or in any other manner inconsistent with the Purposes of the United Nations.' Article 2(7) states: 'Nothing contained in the present Charter shall authorize the United Nations to intervene in matters which are essentially within the domestic jurisdiction of any state or shall require the Members to submit such matters to settlement under the present Charter; but this principle shall not prejudice the application of enforcement measures under Chapter VII" In the same time the charter its self leaves some space of interpretation for humanitarian intervention, especially in the Preamble and in the Article 1 when human rights are stated to be the main purpose of the United Nations. Article 1(2): 'To develop friendly relations among nations based on respect for the principle of equal rights and self-determination of peoples, and to take other appropriate measures to strengthen universal peace'; and in Article 1(3): 'To achieve international cooperation in solving international problems of an economic, social, cultural or humanitarian character, and in promoting and encouraging respect for human rights and for fundamental freedoms for all without distinction as to race, sex, language or religion'. Also in the article 55 it is stated that UN shall promote 'universal respect for, and observance of, human rights and fundamental freedoms for all'. So we may say that human rights and the sovereignty principle are both sanctioned in the UN charter. ${ }^{107}$ But through the Chapter VII of United Nations Charter, UN is enabled to empower regional organizations and actors to carry out military activities to restore international peace ${ }^{108}$

If we take a look on world's history we understand that human's rights became a priority after the Word War II, and especially after the Cold War ended. Since then world was is) faced with many cases which raised the dilemma of humanitarian intervention or non-intervention. Before going to the interpretation of some cases of humanitarian intervention or non-intervention we should analyse briefly the concept of humanitarian intervention. Intervention is mostly described as, "The use of armed force by one or more states or international bodies in another state without the consent of its authorities with the purpose of preventing widespread suffering or death among the inhabitants"109. There are many studies, researches that are focused in one simple and difficult question in the same time, whether states should intervene military or they shouldn't intervene in case of genocide, ethnic cleansing and other anti-human crimes. The world has faced this question many times, in the military interventions in Kosovo, East Timor, Bosnia and Iraq and non-intervention in the Sudan, Rwanda etc. The answer of this question becomes even more difficult in case when states use humanitarian intervention as an excuse for other purposes. ${ }^{110}$

106 Welsh J M, Humanitarian Intervention and International Relations , (Oxford University Press 2006), pg.73

${ }^{107}$ Krasner S D, 'Sovereignty', (2001) 122 Foreign Policy 22

${ }^{108}$ Heir A, Humanitarian Intervention After Kosovo-Iraq, Darfur and the Record of Global Civil Society,(Palgrave Macmillan, 2008)

${ }^{109}$ Abiew F K, The Evolution of the Doctrine and Practice of Humanitarian Intervention, (Martinus Nijhoff Publishers, 1999), pg. 18

${ }^{110}$ Goodman R, 'Humanitarian Intervention and Pretexts for War', (2006) 100 (1) The American Journal of International Law 107-141 
After 90-ties, the concept of Sovereignty becomes more intervention friendly. As it is described in these words, "The Charter to be sure is much more specific on respect for sovereignty than on respect for human rights, but since the day it was drafted the world has witnessed a gradual shift in that balance, making the respect for human rights more mandatory and respect for sovereignty less absolute. Today we regard it as a generally accepted rule of international law, that no sovereign State has the right to terrorize its own citizens"111. Considering human rights as the most important aspect of this new era, we found a very strong endorsement for the new concept of Sovereignty in a speech of former British Prime Minister Tony Blair, saying that, "We must act to save thousands of innocent men, women, and children from humanitarian catastrophe, from death, barbarism, and ethnic cleansing." 112

\section{Cas es of Intervention}

\subsection{Humanitarian Interventions in Balkans}

Yugoslavia's crises demonstrated a huge violation of fundamental human rights, and took the immediate attention of International Community, especially about responding toward crises. Humanitarian intervention was the solution, though it wasn't realized in proper time. UN through military actions (1992) tried to settle down the conflict between Bosnia and Federal Republic of Yugoslavia (Serbia), but the action was not seriously endorsed by international community. Massacre of Srebrenica and the "guilty feeling" made possible a true international community engaged intervention. NATO with the consent of UN intervened in 1995, in the name of humanity.

Years later (1999) another episode of Yugoslavia crises needed attention about intervention. In Kosovo it happened almost the same human catastrophe situations as in Bosnia, many people were killed, companied by ethnic cleansing and almost a million people were deported, in neighbour countries and not only. With the pretext that Kosovo Albanians were supporting the separatist Kosovo Liberation Army (KLA), the Serbs started a series of actions against them. Kosovo was becoming another Bosnia, though international community was not acting same way. In this case NATO intervened without a clear mandate from UN, but the situation in terrain was escalating in a dramatic way, and intervention was more than necessary.

In case of Kosovo, NATO humanitarian intervention was enunciating one side of the sovereignty as the interpretation of sovereignty as a relation between people and state. It was Serbia under Milosevic regime, which abused with the idea of sovereignty by violating the rights of people. Sovereignty doesn't give the right to the leaders or States to kill their citizens or do ethnic cleansing. In his article Kofi Annan confirms that,

'The people's rights are the real source of state sovereignty. This sovereignty can't be covered through the doctrine of non-intervention, for maltreatments, deportation or evaporation of population or of an important segment of it. Furthermore, state is a voluntary union of its citizens. Nothing can't or shouldn't prevent the citizens to freely divide from an existing country with the idea of creating a new state. So, the creation of a state is the act of will of its components, so the abandonment of the state based on expressed will, can be possible-according to this point of view. In this case, the organized international community intervened to protect a population from massive maltreatment of the same authorities that were pretending that were representing it-by exercising the responsibility to protect. Seen by this perspective, the actions of NATO towards Kosovo, served as a huge guide to instruct the

international practice, in the first steps of humanitarian act to protect the populations under risk. 113 This new approach of sovereignty concept opens route for a more proactive attitude of international community regarding intervention issues. In a significant way Christopher Greenwood makes a question in his article:

${ }^{111}$ UN Doc. S/PV.4011, at 12.

112 Tony Blair speech at the Labour Party Conference (2 October 2001) available at http://cnn.com/2001/WORLD/europe/10/02/ret.blair.address/index.html

113 Weller M , Contested statehood: The international Administration of Kosovo's Struggle for Independence, (Prishtine: Koha, March 2009), pg.36 
“... where does the world go from here?

Two comments seem ap propriate by way of conclusion. First, the Kosovo case reinforces the message that an oppressive government can no longer violate the most basic tenets of human rights and international humanitarian law, inflict loss of life and misery on a huge scale upon part of its population and expect to hide behind the concept of State sovereignty in order to escape the consequences of its actions. It makes clear that we are no longer living in a legal system which effectively makes intervention to prevent a holocaust a greater crime than the holocaust itself" 114

This is just one side of the medal for the humanitarian intervention, differently from the respond of International community toward the Yugoslavia crises; some other atrocities didn't have the same opportunity and attention. In cases of Darfur or Rwanda sovereignty or lack of interest of international community was a mayor problem that they didn't "enjoy" the benefits of humanitarian intervention. The Western Sudan, Darfur was an arena of conflict in 2003, where enormous violations of human rights, were done by militia, supported from Government of Sudan. The case of Darfur is a combination of armed conflict and extreme physical and sexually violence. "Since early 2003, the world has watched with both shock and apathy as Sudan's Arab-dominated government ethnically cleanses its vast western region of Darfur by arming, encouraging, and giving air support to mostly Arab militias who kill, maim, rape, and rob black Africans." ${ }^{115}$ Even worse is the case of non-intervention in Rwanda, where world stand without doing anything," Failures to intervene to prevent mass slaughter, as in Rwanda, have raised questions about the international community's commitment to upholding universal human rights" 116

\section{Conclusions}

In all cases the United Nations is seen insufficient mechanism to complete the actions. In the case of Bosnia there was an international mandate but the international community didn't have the will to and it was the massacre of Srebrenica that awakened these actors to intervene seriously in 1995 and to go towards Dayton Accords in 1995.In case of Kosovo, it was missing a clear mandate (for this issue there is still an open international debate if the international community has had any mandate to intervene), but it was the will of the international community to intervene and they intervened with or without the legitimacy and they got the mandate only when the intervention was done and the actors had agreed peace in terrene. What do we understand by both cases? United Nations are a mechanism that gets in actions with huge difficulties because of the bureaucracy and the policies that puts in question the UN's ability to protect the world peace and to promote and protect the Human Rights In the other side, great powers are capable to act faster and they can skip the bureaucracies of the United Nations, but they don't have the moral authority that UN represents. So, now a day's it still remains a big dilemma how to find the solutions to functionalise the cooperation between great powers, regional organisations (for example NATO) and such as United Nations that have the legitimacy, the moral authority and the capacity to intervene in case of genocides, atrocities etc.

With the new interpretation of sovereignty, human rights took more space making sovereignty concept less absolute. Humanitarian intervention by international community has managed to be the solution for most of the crises after 90'ties, making the world more human rights oriented. UN needs to reshape in order to respond toward the needs of new era. Great Powers should engage more with the UN to make interventions less legally discussed.

\footnotetext{
${ }^{114}$ Greenwood C, 'Humanitarian Intervention: The Case of Kosovo' (2002) Finnish Yearbook of International Law $\quad$ pg $174 \quad$ available at http://eprints.lse.ac.uk/21492/1/Humanitarian_intervention_the_case_of_Kosovo(LSERO).pdf

115 Udombana NJ, 'The Darfur Crisis and the Crisis of Humanitarian Intervention in Sudan', (2005) 27 (4) Human Rights Quarterly 1149-1150

116 Welsh J M, Humanitarian Intervention and International Relations, ,(Oxford University Press 2006), pg 176
} 


\section{Bibliography}

1. Abiew F K, The Evolution of the Doctrine and Practice of Humanitarian Intervention, (Martinus Nijhoff Publishers, 1999)

2. Heir A, Humanitarian Intervention After Kosovo-Iraq, Darfur and the Record of Global Civil Society,(Palgrave Macmillan, 2008)

3. Gourevitch V, Rousseau, The Social Contract and other later Political Writings (Cambridge: Cambridge University Press, 1997)

4. Miller R, Respectable Oppressors, Hypocritical Liberators', in Deen Chatterjee and Don Scheid (eds), Ethics and Foreign Intervention,(Cambridge: Cambridge University Press, 2003)

5. Weller M, Contested statehood: The international Administration of Kosovo's Struggle for Independence, (Prishtine: Koha, March 2009)

6. Welsh J M, Humanitarian Intervention and International Relations ,(Oxford University Pres s 2006)

7. ARTICLES:

8. Annan K, 'Two Concepts of Sovereignty', (1999) The Economist

9. Goodman R, 'Humanitarian Intervention and Pretexts for War', (2006) 100 (1) The American Journal of International Law 107-141

10. Krasner S D, 'Sovereignty', (2001) 122 Foreign Policy 22

11. Udombana NJ, 'The Darfur Crisis and the Crisis of Humanitarian Intervention in Sudan', (2005) 27 (4) Human Rights Quarterly 1149-1150

12. DOCUMENTS:

13. Document of the Copenhagen Meeting of the Conference on the Human Dimension of the Conference for Security and Cooperation in Europe 29 June 1990

14. UN Doc. S/PV.4011, at 12

\section{Web-Pages :}

1. Greenwood C, 'Humanitarian Intervention: The Case of Kosovo' (2002) Finnish Yearbook of International Law page 174 available at

2. http://eprints.lse.ac.uk/21492/1/Humanitarian_intervention_the_case_of_Kosovo(LSERO).pdf

3. Tony Blair speech at the Labour Party Conference (2 October 2001) available at http://cnn.com/2001/WORLD/europe/10/02/ret.blair.address/index.html 